\title{
Evaluation of Some Insecticides against Insect Pests of Cauliflower (Brassica oleracea var. botrytis L.)
}

\author{
Pankaj Neog* \\ Department of Entomology, School of Agricultural Sciences and Rural Development \\ Nagaland University, Medziphema, Ngaland, India \\ *Corresponding author
}

\begin{abstract}
A B S T R A C T
Keywords

Insecticides,

Cauliflower,

Brevicoryne

brassicae, Pieris

canidia, Benefit

cost ratio

Article Info

Accepted:

07 November 2020

Available Online:

10 December 2020

A field experiment was conducted to evaluate eight insecticides viz., Emamectin benzoate 5\% SG @0.3 g/lit, Spinosad 45\% SC @ $0.5 \mathrm{ml} / \mathrm{lit}$, Thiacloprid 21.7\% SC@0.3 ml/lit, Indoxacarb 14.5\% SC @ 0.75 ml/lit, Imidacloprid17.8\% SL @ $0.3 \mathrm{ml} / \mathrm{lit}$, Thiamethoxam 30\% FS @0.3 ml/lit, Chlorantraniliprole 18.5\% SC @ $0.3 \mathrm{ml} /$ lit and Cartap Hydrochloride 50 SP @ $1.5 \mathrm{ml} /$ lit against cabbage aphid, Brevicoryne brassicae and cabbage butterfly, Pieris canidia on cauliflower. The result indicated that imidacloprid $17.8 \%$ SL recorded the highest (84.57 to $85.88 \%$ ) reduction of aphid population followed by thiamethoxam 30\% FS and thiacloprid $21.7 \%$ SC. The bio pesticide Spinoasd $45 \%$ SC recorded the highest (82.70 to $89.94 \%$ ) reduction of cabbage butterfly population followed by emamectin benzoate 5\% SG ( 80.15 to $83.28 \%)$. The benefit cost ratio was the highest in thiacloprid $21.7 \%$ SC (18.33:1) followed by thiamethoxam $30 \%$ FS (15.24:1) and Imidacloprid $17.8 \%$ SL (12.55:1).

\section{Introduction}

Cauliflower, Brassica oleracea var. botrytis (L.) belongs to the family Cruciferae is one of the important winter vegetable crops in India. It is a cool weather crop that is closely related to broccoli and cabbage.

Cauliflower can be grown in a wide range of soil with good fertility and good water regime. Fairly deep, loamy, rich in organic matter and well drained soil is preferable for growing cauliflower. The optimum $\mathrm{p}^{\mathrm{H}}$ for cauliflower is 6.0-6.5. The optimum

temperatures for curd formation are 15 to $22^{\circ} \mathrm{C}$, with an average maximum of $25^{\circ} \mathrm{C}$ and average minimum of $8^{\circ} \mathrm{C}$.

Insect pest problem is one of the major constraints for achieving higher production in horticultural crops. During cultivation cauliflower attracts many insect pests which act as a limiting factor in the profitable cultivation of this crop (Abrol and Gupta, 2010). The major insect pests of this crop are cabbage butterfly (Pieris brassicae) and aphids (Lipaphis erysimi) which cause about 5 to $100 \%$ damage (Sachin and Gangwar,
\end{abstract}


1990). Diamond back moth, Plutella xylostella (Lepidoptera: Plutellidae) is also a serious pest of Cole crops and has a great economic importance worldwide (You and Wei, 2007). The damage is caused by its larvae which skeletonises the foliage part of the host plant and renders it unfit for consumption. It infests the plants at all growing stages causing defoliation, leaf curling and stunting of the plant. Cabbage butterfly, Pieris spp. (Linn.) is one of the most serious pests of the cruciferous crops causing about 20 to 100 per cent damage (Sachan and Gangwar, 1990).

As a quick solution, insecticides are the key tool in enhancing the agricultural production (Mehmood et al., 2001). However, the excessive and haphazard use has not only caused environmental pollution but also led to the development of resistance, pest resurgence and adversely affected beneficial organisms. With increasing concerns of excessive use of chemical fertilizers and pesticides in agriculture, the non-synthetic pest control approaches seem to be novel alternatives of chemical insecticides and have high potential which may play an important role in future IPM programmes.

Despite having some effects on human health and environment, use of chemical pesticides is indispensable in order to bring down pests population by striking the weakest point of insect pests. Keeping in view of this, the present investigation was taken to evaluate the efficacy of some synthetic insecticides and bio-pesticides against insect pests of cauliflower.

\section{Materials and Methods}

Field experiment was carried out at School of Agricultural Sciences and Rural Development, Nagaland University, Medziphema Campus during Rabi season of
2016-2017 to evaluate the efficacy of some synthetic insecticides and bio-pesticides against the major insect pests of cauliflower. A susceptible variety SF kartika was sown and raised as per recommended package of practices except insect pest management practices. The experiment was laid out in a Randomized Block Design (RBD) with 9 treatments including untreated control, each replicated thrice. The insecticide treatments were Emamectin benzoate 5\% SG @ $0.3 \mathrm{~g} / \mathrm{lit}$, Spinosad 45\% SC @ 0.5 ml/lit, Thiacloprid 21.7\% SC @ 0.3 ml/lit, Indoxacarb 14.5\% SC @ $0.75 \mathrm{ml} / \mathrm{lit}$, Imidacloprid 17.8\% SL @ 0.3 $\mathrm{ml} / \mathrm{lit}$, Thiamethoxam 30\% FS @ $0.3 \mathrm{ml} / \mathrm{lit}$, Chlorantraniliprole 18.5\% SC @ $0.3 \mathrm{ml} / \mathrm{lit}$ and Cartap Hydrochloride 50 SP @ $1.5 \mathrm{ml} / \mathrm{lit}$. Two sprays were given at 15 days interval using 625 litres of spray volume per hectare when the population exceeded beyond the prescribed economic threshold level (ETL).

The observations on the efficacy of the synthetic insecticides and bio-pesticides were recorded as pre-treatment and post-treatment count. Pre-treatment count was done one day before both first and second sprayings and post-treatment count was recorded at 3, 7 and 14 days after the respective sprayings to observe the efficacy of the insecticides. The pre treatment and post-treatment observation on aphids population was recorded from 5 randomly selected plants per plot. The aphid population was recorded by counting the number of adults as well as nymphs from three leaves i.e., top, middle and bottom leaves per plant. The larvae of cabbage butterfly were counted by inspecting 5 randomly selected plants from each plot. To assess the efficacy of each treatment, the per cent reduction of pest population was calculated from the following formula:

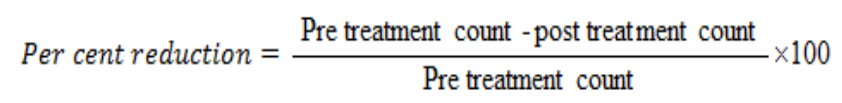


Data obtained were subjected to statistical analysis of variance after suitable transformations. Economics of different insecticide treatments were calculated according to prevailing market price of inputs and outputs. The benefit cost ratio (BCR) was calculated as:

\section{$\mathrm{BCR}=$ \\ Net return (Profit due to treatments)}

\section{Results and Discussion}

During the period of investigation, two insects viz., Cabbage aphid, Brevicoryne brassicae (Hemiptera: Aphididae) and Cabbage butterfly, Pieris canidia (Linnaeus) (Lepidoptera: Pieridae) were recorded as major insect pests as they were found in large number and damaged the crop. Eight insecticides including two bio pesticides were evaluated against the two major insect pests of cauliflower during winter season of 20162017. The results thus obtained are presented and discussed under the following headings.

\section{Efficacy of insecticides against cabbage aphid, Brevicoryne brassicae}

The data pertaining to aphid population on one day before spraying and the per cent reduction of population at 3,7 and 14 days after spraying on two different spray schedules are presented in Table 1.

\section{After first spraying}

The initial mean number of population of cabbage aphid, Brevicoryne brassicae on one day before spraying ranged from 10.14 to 15.95 per leaf. After three days of treatment imposition, the highest per cent reduction of 92.12 in population of Brevicoryne brassicae was observed in the plots treated with imidacloprid $17.8 \%$ SL. It was followed by thiacloprid (86.24\%) and thiamethoxam $(84.30 \%)$ which were at par with each other.
The lowest reduction was found in chlorantraniliprole $18.5 \%$ SC $(74.76 \%)$ which was found to be at par with emamectin benzoate $5 \% \mathrm{SG}$. The other treatments like indoxacarb $14.5 \% \mathrm{SC}$, cartap hydrochloride 50 SP and spinosad $45 \%$ SC were also found to be at par with each other during this period.

The observation recorded after seven days of spraying, the highest reduction of cabbage aphid was found in the plots treated with imidacloprid (83.83\%) followed by thiacloprid $(79.05 \%)$ and thiamethoxam (78.41\%). The lowest reduction was found in chlorantraniliprole $\quad 18.5 \%$ SC $\quad(66.65 \%)$ during this period. The reduction of aphid population in the remaining treatments varied from 68.89 to $75.34 \%$.

After 14 days of spraying, the highest reduction of cabbage aphid was found in the plots treated with imidacloprid $17.8 \%$ SL (77.77\%) followed by thiamethoxam $30 \%$ FS (72.26\%), thiacloprid $21.7 \%$ SC $(70.40 \%)$ and indoxacarb $14.5 \%$ SC (67.43\%). Thiacloprid $21.7 \%$ SC and thiamethoxam 30\% FS were found to be at par with each other. The lowest reduction was found in the plot treated with chlorantraniliprole $18.5 \%$ SC $(58.36 \%)$ which was also found to be at with emamectin benzoate 5\% SG and spinosad 45\% SC. However, the effect of all the treatments on the aphid population was significantly superior to the untreated control.

From the present findings, it is evident that all the treatments could significantly reduce the aphid population. The mean data indicated that imidacloprid $17.8 \% \mathrm{SL}$ was the best insecticide which could reduce the aphid population up to $84.57 \%$ followed by thiacloprid $\quad 21.7 \% \quad \mathrm{SC} \quad(78.56 \%)$. Chlorantraniliprole $18.5 \% \mathrm{SC}$ was the least effective insecticide; however, it exhibited a mean of $66.59 \%$ reduction of aphid population. 


\section{After second spraying}

The initial mean number of population of cabbage aphid, Brevicoryne brassicae on one day before spraying ranged from 4.09 to 12.90 per leaf. After three days of treatment, the highest per cent reduction of 95.08 in population of Brevicoryne brassicae was observed in the plots treated with imidacloprid $17.8 \%$ SL. It was followed by thiamethoxam 30\% FS (88.29\%), thiacloprid $21.7 \%$ SC (87.08\%) and cartap hydrochloride 50 SP (85.63\%) which were statistically found to be at par with each other. The lowest reduction was found in the plots treated with chlorantraniliprole $18.5 \%$ SC (71.76\%) which was at par with emamectin benzoate 5\% SG. Similarly, cartap hydrochloride $50 \mathrm{SP}$ and indoxacarb $14.5 \%$ SC were also found to be at par with each other.

After seven days of spraying, the highest reduction was found in the plot treated with imidacloprid $17.8 \%$ SL (89.29\%) followed by thiacloprid $21.7 \%$ SC $(79.31 \%)$ and thiamethoxam $30 \%$ FS (78.24\%). The latter two were found to be at par with each other. The lowest reduction was found in emamectin benzoate 5\% SG (61.81\%) followed by spinosad $45 \%$ SC (63.62\%) which was at par with chlorantraniliprole $18.5 \%$ SC (65.83\%) during this period. Similarly, cartap hydrochloride $50 \mathrm{SP}$ and indoxacarb $14.5 \%$ SC were also found to be at par with each other.

After 14 days of spraying, the highest reduction in aphid population was found in the plot treated with imidacloprid $17.8 \%$ SL (73.26\%) followed by thiamethoxam 30\% FS $(70.87 \%)$ which were found to be at par with each other. The lowest reduction was observed in spinosad $45 \%$ SC $(52.15 \%)$. The reduction of aphid population in the remaining treatments varied from 54.40 to $67.21 \%$.
From the present findings, it is evident that all the treatments had significantly reduced the aphid population. The mean data on different days of observation after spraying indicated that imidacloprid $17.8 \%$ SL proved to be significantly superior in reducing the aphid population with $85.88 \%$ followed by thiamethoxam 30\% FS (79.13\%). Emamectin benzoate 5\% SG was the least effective insecticide, however, it exhibited a mean of $63.56 \%$ reduction of aphid population. The present findings are in accordance with the findings of earlier workers (Muthukumar et al., 2007). They reported that imidacloprid was the most effective insecticide against aphid and recorded higher mean per cent reduction over the control than thiamethoxam and cartap hydrochloride. The performance of imidacloprid to reduce the population of aphid is good because of its systemic property.

\section{Efficacy of insecticides against cabbage butterfly, Pieris canidia $\mathbf{L}$.}

The data pertaining to cabbage caterpillar population on one day before spraying and the per cent reduction of caterpillar at 3, 7 and 14 days after spraying on two different spray schedules are presented in Table 2.

\section{After first spraying}

The initial mean number of larval population of cabbage butterfly, Pieris canidia L. on one day before spraying ranged from 1.73 to 2.90 per plant. The observation recorded three days after spraying showed the highest reduction in plots treated with spinosad 45\% SC $(96.17 \%)$ followed by emamectin benzoate 5\% SG $(87.97 \%)$ and cartap hydrochloride 50 SP $(82.67 \%)$. The lowest reduction of Pieris canidia was observed in the plots treated with indoxacab $14.5 \%$ SC (57.66\%). The reduction of caterpillar population in the remaining treatments varied from 67.77 to $79.62 \%$. 
Table.1 Efficacy of different insecticides in reducing the population of Cabbage aphid, Brevicoryne brassicae during November, 2016 to January, 2017

\begin{tabular}{|c|c|c|c|c|c|c|c|c|c|c|c|}
\hline \multirow{3}{*}{ Treatments } & \multirow{3}{*}{$\begin{array}{c}\text { Dose } \\
\text { (ml or } \\
\text { g/lit) }\end{array}$} & \multicolumn{4}{|c|}{ First Spray } & \multicolumn{5}{|c|}{ Second Spray } & \multirow{3}{*}{ Mean } \\
\hline & & \multirow{2}{*}{$\begin{array}{c}1 \text { DBS } \\
\text { (Number per } \\
\text { leaf) }\end{array}$} & \multicolumn{3}{|c|}{ Per cent reduction } & \multirow[b]{2}{*}{ Mean } & \multirow{2}{*}{$\begin{array}{c}1 \text { DBS } \\
\text { (Number per } \\
\text { leaf) }\end{array}$} & \multicolumn{3}{|c|}{ Per cent reduction } & \\
\hline & & & $3 \mathrm{DAS}$ & 7 DAS & 14 DAS & & & $3 \mathrm{DAS}$ & $7 \mathrm{DAS}$ & 14 DAS & \\
\hline Thiacloprid & 0.30 & $\begin{array}{l}12.55 \\
(3.61)\end{array}$ & $\begin{array}{l}86.24 \\
(68.25)\end{array}$ & $\begin{array}{c}79.05 \\
(62.79)\end{array}$ & $\begin{array}{c}70.40 \\
(57.06)\end{array}$ & 78.56 & $\begin{array}{c}4.99 \\
(0.23)\end{array}$ & $\begin{array}{c}87.08 \\
(69.02)\end{array}$ & $\begin{array}{c}79.31 \\
(62.97)\end{array}$ & $\begin{array}{c}67.21 \\
(55.12)\end{array}$ & 77.87 \\
\hline Imidacloprid & 0.30 & $\begin{array}{l}15.20 \\
(3.96)\end{array}$ & $\begin{array}{c}92.12 \\
(73.71)\end{array}$ & $\begin{array}{c}83.83 \\
(66.34)\end{array}$ & $\begin{array}{c}77.77 \\
(61.87)\end{array}$ & 84.57 & $\begin{array}{c}4.09 \\
(2.14)\end{array}$ & $\begin{array}{l}95.08 \\
(77.34)\end{array}$ & $\begin{array}{c}89.29 \\
(70.91)\end{array}$ & $\begin{array}{c}73.26 \\
(58.93)\end{array}$ & 85.88 \\
\hline $\begin{array}{c}\text { Cartap } \\
\text { hydrochloride }\end{array}$ & 1.50 & $\begin{array}{l}12.65 \\
(3.63)\end{array}$ & $\begin{array}{c}79.28 \\
(62.93)\end{array}$ & $\begin{array}{c}72.13 \\
(58.16)\end{array}$ & $\begin{array}{c}64.36 \\
(53.35)\end{array}$ & 71.92 & $\begin{array}{c}9.63 \\
(3.18)\end{array}$ & $\begin{array}{c}85.63 \\
(67.75)\end{array}$ & $\begin{array}{c}69.89 \\
(56.75)\end{array}$ & $\begin{array}{c}58.98 \\
(50.18)\end{array}$ & 71.50 \\
\hline Spinosad & 0.50 & $\begin{array}{l}10.84 \\
(3.37)\end{array}$ & $\begin{array}{c}77.94 \\
(62.05)\end{array}$ & $\begin{array}{c}70.23 \\
(56.98)\end{array}$ & $\begin{array}{c}61.16 \\
(51.46)\end{array}$ & 69.78 & $\begin{array}{c}7.22 \\
(2.77)\end{array}$ & $\begin{array}{c}76.61 \\
(61.11)\end{array}$ & $\begin{array}{c}63.62 \\
(52.93)\end{array}$ & $\begin{array}{c}52.15 \\
(46.23)\end{array}$ & 64.13 \\
\hline Indoxacarb & 0.75 & $\begin{array}{l}10.14 \\
(3.26)\end{array}$ & $\begin{array}{c}81.04 \\
(64.20)\end{array}$ & $\begin{array}{c}75.34 \\
(60.35)\end{array}$ & $\begin{array}{c}67.43 \\
(55.22)\end{array}$ & 74.60 & $\begin{array}{c}9.32 \\
(3.13)\end{array}$ & $\begin{array}{c}83.84 \\
(66.32)\end{array}$ & $\begin{array}{c}68.41 \\
(55.81)\end{array}$ & $\begin{array}{c}57.24 \\
(49.16)\end{array}$ & 69.83 \\
\hline $\begin{array}{c}\text { Emamectin } \\
\text { benzoate }\end{array}$ & 0.30 & $\begin{array}{l}13.76 \\
(3.77)\end{array}$ & $\begin{array}{c}76.81 \\
(61.31)\end{array}$ & $\begin{array}{c}68.89 \\
(56.10)\end{array}$ & $\begin{array}{c}60.23 \\
(50.90)\end{array}$ & 68.64 & $\begin{array}{l}12.90 \\
(3.66)\end{array}$ & $\begin{array}{c}74.46 \\
(59.64)\end{array}$ & $\begin{array}{c}61.81 \\
(51.83)\end{array}$ & $\begin{array}{c}54.40 \\
(47.53)\end{array}$ & 63.56 \\
\hline Chlorantraniliprole & 0.30 & $\begin{array}{l}15.95 \\
(4.05)\end{array}$ & $\begin{array}{c}74.76 \\
(59.85)\end{array}$ & $\begin{array}{c}66.65 \\
(54.74)\end{array}$ & $\begin{array}{c}58.36 \\
(49.82)\end{array}$ & 66.59 & $\begin{array}{l}12.24 \\
(3.57)\end{array}$ & $\begin{array}{c}71.67 \\
(57.91)\end{array}$ & $\begin{array}{c}65.83 \\
(54.26)\end{array}$ & $\begin{array}{c}56.33 \\
(48.64)\end{array}$ & 64.61 \\
\hline Thiamethoxam & 0.30 & $\begin{array}{l}12.76 \\
(3.64)\end{array}$ & $\begin{array}{c}84.30 \\
(66.66)\end{array}$ & $\begin{array}{c}78.41 \\
(62.47)\end{array}$ & $\begin{array}{c}72.26 \\
(58.25)\end{array}$ & 78.32 & $\begin{array}{c}5.84 \\
(2.52)\end{array}$ & $\begin{array}{c}88.29 \\
(69.99)\end{array}$ & $\begin{array}{c}78.24 \\
(62.21)\end{array}$ & $\begin{array}{c}70.87 \\
(57.35)\end{array}$ & 79.13 \\
\hline Control & -------- & $\begin{array}{l}10.20 \\
(3.27)\end{array}$ & $\begin{array}{c}0 \\
(0.00)\end{array}$ & $\begin{array}{c}0 \\
(0.00)\end{array}$ & $\begin{array}{c}0 \\
(0.00)\end{array}$ & 0 & $\begin{array}{l}10.29 \\
(3.28)\end{array}$ & $\begin{array}{c}0 \\
(0.00)\end{array}$ & $\begin{array}{c}0 \\
(0.00)\end{array}$ & $\begin{array}{c}0 \\
(0.00)\end{array}$ & 0 \\
\hline SEm \pm & & 0.24 & 1.06 & 1.55 & 0.92 & & 0.37 & 1.03 & 1.07 & 1.14 & \\
\hline $\mathrm{CD}(\mathrm{p}=0.05)$ & & NS & 3.19 & 4.66 & 2.77 & & NS & 3.09 & 3.20 & 3.43 & \\
\hline
\end{tabular}

DBS- Days before spraying, DAS - Days after spraying, Figures in parenthesis are $\sqrt{(\mathrm{X}}+0.5)$ values for number of aphid/leaf on 1 DBS and angular transformed values for per cent reduction of aphid 
Table.2 Efficacy of different insecticides in reducing the population of Cabbage butterfly, Pieris canidia during November, 2016 to January, 2017

\begin{tabular}{|c|c|c|c|c|c|c|c|c|c|c|c|}
\hline \multirow{3}{*}{ Treatments } & \multirow{3}{*}{$\begin{array}{l}\text { Dose } \\
\text { (ml or } \\
\text { g/lit) }\end{array}$} & \multicolumn{4}{|c|}{ First Spray } & \multicolumn{5}{|c|}{ Second Spray } & \multirow{3}{*}{ Mean } \\
\hline & & \multirow{2}{*}{$\begin{array}{c}1 \mathrm{DBS} \\
\text { (Number per } \\
\text { plant) }\end{array}$} & \multicolumn{3}{|c|}{ Per cent reduction } & \multirow[b]{2}{*}{ Mean } & \multirow{2}{*}{$\begin{array}{c}1 \mathrm{DBS} \\
\text { (Number } \\
\text { per plant) }\end{array}$} & \multicolumn{3}{|c|}{ Per cent reduction } & \\
\hline & & & 3 DAS & 7 DAS & 14 DAS & & & $3 \mathrm{DAS}$ & 7 DAS & 14 DAS & \\
\hline Thiacloprid & 0.30 & $\begin{array}{c}2.09 \\
(1.61)\end{array}$ & $\begin{array}{c}79.62 \\
(63.23)\end{array}$ & $\begin{array}{c}74.46 \\
(59.74)\end{array}$ & $\begin{array}{c}60.11 \\
(50.90)\end{array}$ & 71.40 & $\begin{array}{c}1.43 \\
(1.61)\end{array}$ & $\begin{array}{c}78.05 \\
(62.51)\end{array}$ & $\begin{array}{c}70.75 \\
(57.40)\end{array}$ & $\begin{array}{c}62.80 \\
(52.72)\end{array}$ & 70.53 \\
\hline Imidacloprid & 0.30 & $\begin{array}{c}1.73 \\
(1.42)\end{array}$ & $\begin{array}{c}67.77 \\
(55.44)\end{array}$ & $\begin{array}{c}60.32 \\
(51.05)\end{array}$ & $\begin{array}{c}52.19 \\
(46.27)\end{array}$ & 60.09 & $\begin{array}{c}1.43 \\
(1.42)\end{array}$ & $\begin{array}{c}84.89 \\
(67.22)\end{array}$ & $\begin{array}{c}77.86 \\
(61.96)\end{array}$ & $\begin{array}{c}68.28 \\
(55.75)\end{array}$ & 77.01 \\
\hline $\begin{array}{c}\text { Cartap } \\
\text { hydrochloride }\end{array}$ & 1.50 & $\begin{array}{c}2.39 \\
(1.64)\end{array}$ & $\begin{array}{c}82.67 \\
(65.73)\end{array}$ & $\begin{array}{c}83.59 \\
(66.16)\end{array}$ & $\begin{array}{c}73.36 \\
(59.06)\end{array}$ & 79.87 & $\begin{array}{c}1.32 \\
(1.64)\end{array}$ & $\begin{array}{c}73.84 \\
(60.82)\end{array}$ & $\begin{array}{c}80.70 \\
(64.09)\end{array}$ & $\begin{array}{c}72.58 \\
(58.51)\end{array}$ & 75.71 \\
\hline Spinosad & 0.50 & $\begin{array}{c}1.99 \\
(1.52)\end{array}$ & $\begin{array}{c}96.17 \\
(78.83)\end{array}$ & $\begin{array}{c}92.74 \\
(74.48)\end{array}$ & $\begin{array}{c}80.91 \\
(64.14)\end{array}$ & 89.94 & $\begin{array}{c}1.30 \\
(1.54)\end{array}$ & $\begin{array}{c}86.85 \\
(68.94)\end{array}$ & $\begin{array}{c}83.85 \\
(66.31)\end{array}$ & $\begin{array}{c}77.39 \\
(61.64)\end{array}$ & 82.70 \\
\hline Indoxacarb & 0.75 & $\begin{array}{c}1.90 \\
(1.62)\end{array}$ & $\begin{array}{c}57.66 \\
(49.43)\end{array}$ & $\begin{array}{c}53.37 \\
(47.03)\end{array}$ & $\begin{array}{c}50.50 \\
(45.31)\end{array}$ & 53.84 & $\begin{array}{c}2.04 \\
(1.62)\end{array}$ & $\begin{array}{c}83.74 \\
(66.720\end{array}$ & $\begin{array}{c}72.41 \\
(58.33)\end{array}$ & $\begin{array}{c}62.47 \\
(52.25)\end{array}$ & 72.87 \\
\hline Emamectin benzoate & 0.30 & $\begin{array}{c}2.90 \\
(1.54)\end{array}$ & $\begin{array}{c}87.97 \\
(69.83)\end{array}$ & $\begin{array}{c}82.42 \\
(65.24)\end{array}$ & $\begin{array}{c}79.44 \\
(63.10)\end{array}$ & 83.28 & $\begin{array}{c}1.66 \\
(1.54)\end{array}$ & $\begin{array}{c}88.03 \\
(70.29)\end{array}$ & $\begin{array}{c}82.06 \\
(65.34)\end{array}$ & $\begin{array}{c}70.36 \\
(57.20)\end{array}$ & 80.15 \\
\hline Chlorantraniliprole & 0.30 & $\begin{array}{c}1.95 \\
(1.31)\end{array}$ & $\begin{array}{c}77.02 \\
(61.52)\end{array}$ & $\begin{array}{c}71.51 \\
(57.86)\end{array}$ & $\begin{array}{c}67.27 \\
(55.18)\end{array}$ & 71.93 & $\begin{array}{c}1.56 \\
(1.31)\end{array}$ & $\begin{array}{c}69.90 \\
(57.20)\end{array}$ & $\begin{array}{c}61.26 \\
(51.55)\end{array}$ & $\begin{array}{c}56.13 \\
(48.55)\end{array}$ & 62.43 \\
\hline Thiamethoxam & 0.30 & $\begin{array}{c}2.14 \\
(1.61)\end{array}$ & $\begin{array}{c}71.83 \\
(58.05)\end{array}$ & $\begin{array}{c}67.79 \\
(55.56)\end{array}$ & $\begin{array}{c}65.24 \\
(53.97)\end{array}$ & 68.29 & $\begin{array}{c}1.89 \\
(1.61)\end{array}$ & $\begin{array}{c}68.89 \\
(56.43)\end{array}$ & $\begin{array}{c}60.30 \\
(51.14)\end{array}$ & $\begin{array}{c}53.21 \\
(46.96)\end{array}$ & 60.8 \\
\hline Control & -------- & $\begin{array}{c}0 \\
(0.00)\end{array}$ & $\begin{array}{c}0 \\
(0.00)\end{array}$ & $\begin{array}{c}0 \\
(0.00)\end{array}$ & $\begin{array}{c}0 \\
(0.00)\end{array}$ & & $\begin{array}{c}1.13 \\
(2.14)\end{array}$ & $\begin{array}{c}0 \\
(0.00)\end{array}$ & $\begin{array}{c}0 \\
(0.00)\end{array}$ & $\begin{array}{c}0 \\
(0.00)\end{array}$ & 0 \\
\hline SEm \pm & & 0.20 & 2.06 & 2.79 & 2.78 & & 0.17 & 4.70 & 2.26 & 3.03 & \\
\hline $\mathrm{CD}(\mathrm{p}=0.05)$ & & NS & 6.17 & 8.36 & 8.34 & & NS & 14.10 & 6.78 & 9.09 & \\
\hline
\end{tabular}

DBS- Days before spraying, DAS - Days after spraying, Figures in parenthesis are $\sqrt{(\mathrm{X}}+0.5)$ values for number of Pieris canidia per plant on 1 DBS and angular transformed values for per cent reduction of Pieris canidia 
Table.3 Economics of different insecticide treatments against major insect pests of cauliflower during October, 2016 to January, 2017

\begin{tabular}{|c|c|c|c|c|c|c|c|c|}
\hline Treatments & $\begin{array}{c}\text { Dose } \\
\text { (ml or } \mathrm{g} / \mathrm{ha})\end{array}$ & $\begin{array}{l}\text { No. of } \\
\text { spray }\end{array}$ & $\begin{array}{l}\text { Gross yield } \\
\text { (q/ha) }\end{array}$ & $\begin{array}{l}\text { Additional yield over } \\
\text { control } \\
\text { (q/ha) }\end{array}$ & $\begin{array}{c}\text { Value of } \\
\text { additional yield } \\
\text { (Rs./ha) }\end{array}$ & $\begin{array}{l}\text { Cost of } \\
\text { insecticide } \\
\text { treatments } \\
\text { (Rs.) }\end{array}$ & $\begin{array}{c}\text { Profit due } \\
\text { to } \\
\text { treatments } \\
\text { (Rs.) }\end{array}$ & $\begin{array}{c}\text { Benefit } \\
\text { Cost Ratio }\end{array}$ \\
\hline Emamectin benzoate $5 \%$ SG & 308.64 & 2 & 33.92 & 20.04 & 40080 & 5474.05 & 34605.95 & $6.32: 1$ \\
\hline Spinosad $45 \%$ SC & 514.40 & 2 & 41.97 & 28.09 & 56180 & 18683.84 & 37496.16 & $2.00: 1$ \\
\hline Thiacloprid $21.7 \%$ SC & 308.64 & 2 & 41.49 & 27.61 & 55220 & 2856.78 & 52363.22 & $18.33: 1$ \\
\hline Indoxacarb $14.5 \% \mathrm{SC}$ & 771.60 & 2 & 32.58 & 18.70 & 37400 & 6520.768 & 30879.23 & $4.73: 1$ \\
\hline Imidacloprid $17.8 \%$ SL & 308.64 & 2 & 34.16 & 20.28 & 40560 & 2992.58 & 37567.42 & $12.55: 1$ \\
\hline Thiamethoxam 30\% FS & 308.64 & 2 & 43.62 & 29.74 & 59480 & 3663.36 & 55816.64 & $15.24: 1$ \\
\hline $\begin{array}{l}\text { Chlorantraniliprole } 18.5 \% \\
\text { SC }\end{array}$ & 308.64 & 2 & 33.02 & 19.14 & 38280 & 10144.80 & 28135.20 & $2.77: 1$ \\
\hline Cartap Hydrochloride 50 SP & 1543.21 & 2 & 32.82 & 18.94 & 37880 & 5631.00 & 32249.00 & $5.73: 1$ \\
\hline Control & - & - & 13.88 & & - & - & - & - \\
\hline
\end{tabular}

Cost of insecticides- Emmamectin benzoate- Rs. 660/100g; Spinosad- Rs.1680/100ml; Thiacloprid- Rs. 236/100ml; Indoxacarb- Rs. 332/100ml; Imidacloprid- Rs. 258/100ml; Thiamethoxam- Rs. 220/60ml; Chlorantraniliprole- Rs. 850/60ml; Cartap Hydrocloride- Rs. 1371/1kg

Labour charge @ Rs. 300/day (2 men/day/ha/spray) 3. Rental charge of sprayer @ Rs. 50/day 4. Cost of cauliflower @ Rs. 2000/q 
After seven days of spraying, the highest reduction of cabbage butterfly was found in the plots treated with spinosad $45 \%$ SC $(92.74 \%)$ followed by cartap hydrochloride 50 SP $(83.59 \%)$ and emamectin benzoate $5 \%$ SG $(82.42 \%)$ which were statistically at par with each other. The lowest reduction was found in indoxacab $14.5 \%$ SC $(53.37 \%)$ during this period. The reduction of caterpillar population in the remaining treatments varied from 60.32 to $74.46 \%$.

After 14 days of spraying, the highest reduction of cabbage butterfly was found in the plots treated with spinosad $45 \%$ SC $(80.91 \%)$ followed by emamectin benzoate $5 \%$ SG $(79.44 \%)$ and cartap hydrochloride 50 SP $(73.36 \%)$ which were found to be at par with each other. The other treatments like thiacloprid $\quad 21.7 \% \quad$ SC $\quad(60.11 \%)$, thiamethoxam $30 \%$ FS $(65.24 \%)$ and chlorantraniliprole $18.5 \%$ SC $(67.27 \%)$ were also found to be at par with each other. The lowest reduction was found in indoxacarb $14.5 \%$ SC $(50.50 \%)$ followed by imidacloprid $17.8 \%$ SL (52.19\%). However, all the insecticides were significantly superior over the control in reducing the population of cabbage butterfly.

From the present findings, it is evident that all the treatments could significantly reduce the cabbage butterfly population. The mean data on different days of observation after first spraying indicated that spinosad $45 \%$ SC was the best insecticide which could reduce the caterpillar population up to $89.94 \%$ followed by emamectin benzoate 5\% SG $(83.28 \%)$. Indoxacarb $14.5 \% \mathrm{SC}$ was the least effective insecticide; however, it exhibited a mean of $53.84 \%$ reduction of the pest population.

\section{After second spraying}

The initial mean number of larval population of cabbage butterfly, Pieris canidia L. on one day before spraying ranged from 1.13 to 2.04 per plant. The observation recorded three days after spraying showed the highest per cent reduction in plots treated with emamectin benzoate 5\% SG (88.03) followed by spinosad $45 \%$ SC (86.85), imidacloprid $17.8 \%$ SL (84.89) and indoxacarb $14.5 \%$ SC (83.74) which were found to be statistically at par with each other. The lowest per cent reduction was observed in the plots treated with thiamethoxam 30\% FS (68.89) which was found to be at par with treatments like chlorantraniliprole $18.5 \%$ SC (69.90), cartap hydrochloride $50 \mathrm{SP}$ (73.84) and thiacloprid $21.7 \%$ SC (78.05). After seven days of spraying the highest reduction of cabbage butterfly was found in the plots treated with spinosad $45 \%$ SC $(83.85 \%)$ followed by emamectin benzoate 5\% SG $(82.06 \%)$, cartap hydrochloride $50 \quad \mathrm{SP} \quad(80.70 \%)$ and imidacloprid $17.8 \%$ SL $(77.86 \%)$ which were found to be statistically at par with each other. The lowest reduction was found in the treatment thiamethoxam $30 \%$ FS $(60.30 \%)$ followed by chlorantraniliprole $18.5 \% \mathrm{SC}$ $(61.26 \%)$ which were at par with each other.

The observation recorded after 14 days of spraying showed the highest reduction of cabbage butterfly in the plots treated with spinosad $45 \%$ SC (77.39\%) followed by cartap hydrochloride 50 SP $(72.58 \%)$ and emamectin benzoate 5\% SG $(70.36 \%)$ which were found to be at par with each other. The other treatments like thiacloprid $21.7 \% \mathrm{SC}$ (62.80\%), indoxacarb $14.5 \%$ SC $(62.47 \%)$ and imidacloprid $17.8 \%$ SL $(68.28 \%)$ were also found to be statistically at par with each other. The lowest reduction was found in the treatment with thiamethoxam 30\% FS $(53.21 \%)$ followed by chlorantraniliprole $18.5 \%$ SC $(56.13 \%)$ which were also at par with each other. However, all the insecticides were significantly superior over the control in reducing the population of cabbage butterfly. 
The mean data on different days of observation after second spraying revealed that spinosad $45 \%$ SC was the best insecticide with $82.70 \%$ reduction in cabbage butterfly population followed by emamectin benzoate $5 \%$ SG $(80.15 \%)$. The present finding of both after first and second spraying is in almost conformity with the findings of Rangad et al., (2010) who reported that spinosad was found to give maximum control among the bio pesticides.

\section{Economics of different insecticide treatments against major insect pests of cauliflower}

It is evident from the data presented in Table 3 that the highest cost of insecticide treatments was incurred by spinosad $45 \%$ SC (Rs. 18683.84) followed by chlorantraniliprole 18.5\% SC (Rs. 10114.8), indoxacarb $14.5 \%$ (Rs. 6520.77), cartap hydrochloride 50 SP (Rs. 5631), emamectin benzoate 5\% SG (Rs. 5474.05), thiamethoxam 30\% FS (Rs. 3663.36) and imidacloprid $17.8 \%$ (Rs. 2992.58), while the lowest cost was incurred by thiacloprid $21.7 \%$ SC (Rs. 2856.78).

The highest additional yield was obtained in thiamethoxam 30\% FS (29.74 qt/ha) followed by spinosad $45 \% \mathrm{SC}$ (28.09 qt/ha), thiacloprid $21.7 \%$ SC (27.61 qt/ha), imidacloprid $17.8 \%$ SC (20.28 qt/ha), emamectin benzoate $5 \%$ SG (20.04 qt/ha), chlornatraniliprole $18.5 \% \mathrm{SC}$ (19.14 qt/ha) and cartap hydrochloride $50 \mathrm{SP}$ (18.94 qt/ha). The lowest additional yield among the treatments was obtained from indoxacarb $14.5 \% \mathrm{SC}$ (18.70 qt/ha).

The maximum profit due to treatments was obtained by the treatment thiamethoxam $30 \%$ FS (Rs. 55816.64) followed by thiacloprid $21.7 \%$ SC (Rs. 52363.22), imidacloprid 17.8\% SC (Rs. 37567.42), spinosad 45\% SC (Rs. 37496.16), emamectin benzoate 5\% SG
(Rs. 34605.95), cartap hydrochloride 50 SP (Rs. 32249.00) and indoxacarb 14.5\% SG (Rs. 30879.23). The lowest profit was obtained by chlorantraniliprole $18.5 \%$ SC (Rs. 28135.20).

The maximum benefit cost ratio was in the treatment thiacloprid $21.7 \%$ SC (18.33:1) followed by thiamethoxam $30 \%$ FS (15.24:1) and imidacloprid $17.8 \%$ SL (12.55:1). The lowest was in the treatment spinosad $45 \%$ SC (2.00:1). The benefit cost ratio in the other treatments varied from $2.77: 1$ to $6.32: 1$. The present finding is closely in accordance with the findings of Bhati and Sharma (2014) who reported that thiamethoxam gave the highest BCR. Mishra and Yadav (2011) also reported that imidacloprid gave the highest Benefit Cost Ratio among the treatments.

\section{References}

Abrol, D. P. and Gupta, A. 2010. Insect pests attacking cauliflower (Brassica oleracea var. botrytis L.): 1. Population dynamics in relation to weather factors. Green Farming, 1(2): 167-170.

Bhati, R. and Sharma, R. C. 2014. Efficacy of newer chemicals against mustard aphid. Journal of Biology and Life Sciences, 2(4): 1165-1169.

Mehmood, K., Afzal, M. and Amjad, M. 2001. Non-traditional Insecticides: A New Approach for the Control of Okra Jassid. Journal of Biological Sciences, 1(1): 36-37.

Mishra, D. N. and Yadav, V. 2011. Efficacy and economics of different insecticides against mustard aphid (Lipaphis erysimi) on brown sarson (Brassica compestris). Indian Journal of Agricultural Sciences, 83(8): 893-895.

Muthukumar, M., Sharma, R. K. and Sinha, S. R. 2007. Field efficacy of biopesticides and new insecticides against major 
insect pests and their effect on natural enemies in cauliflower. Pesticide Research Journal, 19 (2): 190-196.

Rangad, R. W., Lytan, D., Waluniba and Firake, D. M. 2010. Bio-efficacy of Eco-friendly Insecticides against Cabbage Butterfly, Pieris brassicae (L.) on Cabbage in the Mid Altitudes Hills of Meghalaya, North East India. Molecular Entomology, 5(8): 1-3.
Seasonal incidence of insect pests of cabbage, cauliflower and knol-khol. Indian Journal of Entomology, 52(1): 111-124.

You, B. C. and Wei, K. I. 2007. Aphicidal activity of some indigenous plant extracts against bean aphid, Aphis craccivora Koch (Homoptera: Aphididae). Journal of Pest Sciences, 81: 152-159.

Sachin, J. N. and Gangwar, S. K. 1990.

\section{How to cite this article:}

Pankaj Neog. 2020. Evaluation of Some Insecticides against Insect Pests of Cauliflower (Brassica oleracea var. botrytis L.). Int.J.Curr.Microbiol.App.Sci. 9(12): 804-813. doi: https://doi.org/10.20546/ijcmas.2020.912.096 